\title{
Community-Based Research (CBR) in the Education Doctorate: Lessons Learned and Promising Practices
}

\author{
Laurie Stevahn, Jeffrey Anderson, and Tana Hasart \\ Seattle University, Seattle, Washington, USA
}

\author{
stevahnl@seattleu.edu janderso@seattleu.edu \\ hasartt@seattleu.edu
}

\begin{abstract}
Community-based research (CBR) is an advanced form of academic service-learning through which university students, faculty, and community organizations collaborate to conduct inquiry projects aimed at producing social change. Despite its potential for advancing learning in graduate studies, little research exists on CBR implementations or outcomes in doctoral programs. This study examined the effectiveness of integrating CBR into an educational leadership doctorate across three consecutive cohorts in which students worked in teams to conduct CBR projects, each in partnership with a community organization pursuing a social justice initiative. A mixedmethods developmental case study design produced quantitative and qualitative data on students' perceived effectiveness of cooperative/collaborative interaction and team decision making in $\mathrm{CBR}$, experience with and learning from $\mathrm{CBR}$ in the education doctorate, and development of CBR competencies. Triangulated results overall revealed students' (a) positive attitudes toward $\mathrm{CBR}$, (b) enhanced understanding of and commitment to CBR and how to conduct it, (c) expanded understanding and application of technical research skills, (d) growth in cooperative/collaborative and conflict resolution skills, and (e) development of leadership project management skills. These findings may assist faculty in planning innovative, authentic, applied, professional training in the education doctorate capable of advancing students' graduate inquiry skills while also enhancing competencies for successful leadership in the field.
\end{abstract}

Keywords: community-based research, academic service-learning, doctoral student development, education doctorate, educational leadership, cooperative learning, experiential learning, projectbased learning

\section{Introduction}

(CC BY-NC 4.0) This article is licensed to you under a Creative Commons AttributionNonCommercial 4.0 International License. When you copy and redistribute this paper in full or in part, you need to provide proper attribution to it to ensure that others can later locate this work (and to ensure that others do not accuse you of plagiarism). You may (and we encourage you to) adapt, remix, transform, and build upon the material for any non-commercial purposes. This license does not permit you to use this material for commercial purposes.
Debates over the fundamental purpose of the education doctorate and experiences that should be required of students in EdD programs have prompted faculty to rethink many taken-for-granted aspects of doctoral studies. Unlike PhD programs that largely aim to prepare life-long scholars who teach and conduct research in university settings, most students in EdD programs are leaders seeking to advance and apply knowledge and skills in organizational settings other than the academy. Many, for example, are (or aspire to become) executive lead- 
ers who serve as superintendents, principals, or program administrators in P-12 education; student affairs administrators in higher education; or directors/coordinators of programs/divisions in business, government, social service agencies, foundations, nonprofits, or faith-based organizations. These professional roles especially require leadership skill sets that include inspiring shared mission/vision/values, facilitating and engaging in cooperative or collaborative teamwork to accomplish common goals, initiating and sustaining organizational learning for optimal effectiveness, managing interpersonal conflict constructively, creatively innovating into the future to meet changing needs, and constantly assessing progress along the way.

A particularly vexing issue in the EdD, therefore, is how to position and prepare students for doctoral inquiry that traditionally culminates in the dissertation. In fact, such inquiry is a hallmark of doctoral studies. One who attains the title of doctor-EdD or $\mathrm{PhD}$ - is expected to know how to access and review scholarly literature, conduct studies to advance knowledge, use the results to inform policy, and apply knowledge to practice. This distinguishes those who seek professional development through the terminal degree from those who seek training through workshops or other types of human resource development programs outside of the academy. Although all types of training aim to advance learning and equip participants with useful skills, the doctorate requires some type of focused in-depth research or inquiry formally reported, evaluated by scholarly standards, and available for public scrutiny; most other types of training do not. Yet, practitioner-scholars in EdD programs primarily will not be conducting and publishing research in their professional roles once the doctorate is earned. Instead, most will be engaged in the daily business of leading programs or organizations, gathering evidence of effectiveness, and using that evidence to shape policy and practice. A challenge for educators in EdD programs, therefore, is how to enable students to meet the challenges of rigorous scholarship required in graduate school while also supporting the development of real-world leadership skills applicable for high-quality practice in the organizations they serve.

We chose to integrate a cooperative form of community-based research (CBR) into our educational leadership doctorate during first-year coursework because of its potential to authentically engage students in practicing leadership, interpersonal, inquiry, and advocacy skills by partnering with a community organization to conduct research perceived to be important for advancing positive social change. Specifically, we wondered the extent to which engaging students at the onset of their doctoral studies in comprehensive, year-long, team-based CBR would enhance their learning and development. We hypothesized that CBR — an advanced form of service-learning would be developmentally appropriate for doctoral students in our EdD program at Seattle University, given their educational background (all with master's degrees), professional roles (most working full-time in mid-level executive leadership positions), and stage in life (many in the 3045 year age range with families of their own). Furthermore, faculty and institutional readiness in our context provided a supportive environment for pursuing CBR, as did the fact that most students who enter our EdD program bring strong interpersonal skills, sensitivity to cultural difference, and experience working with various agencies and organizations in the community.

This article describes our journey with integrating cooperative CBR into the education doctorate. Particularly, we share what we learned from conducting three separate implementations across three consecutive doctoral cohorts, and how our findings have influenced and informed program revisions toward creating a practitioner-scholar EdD model that nurtures pragmatic field-based professional practice as well as rigorous applied inquiry that meets doctoral degree expectations. We begin by briefly describing CBR, its theoretical foundations, and how cooperative learning informed our team-based implementation. We then provide an overview of the literature on CBR in doctoral programs, revealing vast variations in implementation, little information on best practices, and the need for systematic study of comprehensive applications to determine outcomes and factors that support success. After describing the research methods we used to examine our coop- 
erative CBR implementation, we present results, discuss overall effectiveness, revisit underlying theoretical foundations, note strengths and limitations, and suggest implications for current practice and future research. Finally, we consider the overall significance of our findings in light of transforming the EdD to better serve its practitioner-scholar purpose.

\section{Cooperative Community-Based Research}

Our doctoral CBR implementation combined two distinctly recognized instructional approaches, both of which interface with the literatures on student-engaged learning, experiential learning, project-based learning, and academic service-learning. The first is CBR, itself a form of servicelearning, which provides theoretical grounding for structuring educational experiences aimed at transformative outcomes for those involved and the community at large (Strand, Marullo, Cutforth, Stoecker, \& Donahue 2003). CBR directly and authentically connects students to community organizations that serve social change interests to conduct inquiry projects that advance such interests. While conducting CBR in partnership with such organizations, students also simultaneously develop knowledge, skills, and dispositions that support the accomplishment of targeted academic educational outcomes. The second instructional approach is cooperative learning, grounded by social interdependence theory (Deutsch, 1949a, 1949b, 2014; Johnson \& R. Johnson, 1989, 2005, 2011) and five basic elements that reliably predict effective teamwork (Johnson \& F. Johnson, 2017). Cooperative learning provides grounding for structuring CBR as a team endeavor. CBR, cooperative learning, and their underlying theoretical foundations are further elaborated in the sections that follow.

\section{Community-Based Research (CBR)}

CBR is a form of service-learning that incorporates collective action, advocacy, critical reflection, and collaboration for the purpose of social change. CBR also is a model of inquiry in which faculty, students, and community partners collaborate to address community-identified questions or issues by jointly conducting research projects (Stocking \& Cutforth, 2006). Strand et al. (2003) conclude that CBR is an "especially effective, powerful, and transformative kind of servicelearning pedagogy" (p. 121), and Porpora (1999) calls CBR the highest stage of service-learning. In fact, we intentionally choose to integrate CBR into our doctorate from among other instructional strategies because of its potential to support our university mission, which is "dedicated to educating the whole person, to professional formation, and to empowering leaders for a just and humane world" (Seattle University, 2016).

We adopted a CBR model based on three general principles described by Strand et al. $(2003$, p. 8) that differentiate it from other forms of research. First, CBR is a collaborative enterprise between academic researchers (professor and students) and community members. The strong emphasis on collaboration throughout this model underscores the fact that research questions to guide CBR emanate from the community, rather than the community serving as a lab for university-directed research. Second, CBR validates multiple sources of knowledge through collecting and disseminating information in diverse forms. Data are sought from a variety of sources and findings are shared using methods most effective for the communities that will use the results. Third, CBR is change-oriented and is guided by social justice goals. A CBR project is not complete when a final report has been written; knowledge gained through the research process must be applied to support the development of individuals, organizations, and the larger community.

\section{Cooperative Learning}

We framed CBR as a cooperative group endeavor, with students participating in their CBR team of choice, each working with a community-based organization (CBO) to accomplish the mutual goal of successfully addressing the issue important to the CBO. Cooperative learning is an in- 
structional approach in which students in small groups strive to achieve a common goal-in this case, a CBR project that provides useful information to the $\mathrm{CBO}$ for making social change. The goal itself is one that links participants together in positively interdependent ways-i.e., teammates need each other; no one person alone can carry out all of the tasks needed for team success. Instead, it takes everyone's coordinated contributions to complete the year-long CBR project comprised of numerous tasks requiring a range of skills.

Cooperative learning instructional strategies are based on social interdependence theory (Deutsch, 1949a, 1949b, 2014; Johnson \& R. Johnson, 1989, 2005, 2011), which posits that the way goals are structured among participants (cooperatively or competitively) influences social interaction (supportive or obstructive) which, in turn, determines outcomes (mutually or exclusively beneficial/successful). Furthermore, an abundance of empirical evidence indicates that five basic elements underpin effective teamwork (see Johnson \& F. Johnson, 2017; Johnson \& R. Johnson, 2005, 2011). Team success tends to occur when all teammates (a) perceive they are positively interdependent (everyone is needed to accomplish the shared goal), (b) demonstrate individual accountability (carry out responsibilities), (c) engage in promotive face-to-face interaction (facilitate each other's success), (d) use constructive social/interpersonal skills (seek and listen to everyone's input, check for understanding, reach consensus), and (e) process group effectiveness (evaluate what worked well and what needs improvement).

Students in our doctoral program were taught and employed the basic elements of effective teamwork in leadership course/class sessions, and faculty who mentored students in team-based CBR focused attention on these elements throughout. However, faculty did not tightly structure these elements into all CBR tasks, instead coaching groups to self-direct their teamwork toward a successful outcome, which ultimately was to complete a CBR project useful to the CBO and community. Hence, sometimes teammates worked collaboratively, engaging with each other in helpful ways, but without the basic elements of cooperative teamwork deliberately structured into the process (i.e., positive interdependence, individual accountability, face-to-face interaction, social/interpersonal skills, and group processing). Other times teammates worked cooperatively, grounded by the basic elements intentionally built into particular tasks, thereby requiring each member's contribution for mutual success. In summary, cooperative work demands each individual's success for team accomplishment - if all achieve, the team succeeds; if any member fails, the entire team fails. We acknowledge that the terms cooperative and collaborative have different meanings in the literature and, thus, use them distinctly.

\section{Overview of the Literature}

Despite the potential that CBR holds for advancing learning in graduate programs, little research exists on its use or outcomes at the doctoral level. For example, although CBR has grown rapidly throughout the United States and occurs in many forms - from solo practitioners to multi-state collaborative structures that include numerous universities and community organizations - few studies address the use of CBR with doctoral students (Beckman, Brandenberger, \& Smith Shappell, 2009; Tinkler, 2010). The few studies that exist on CBR in the doctorate mostly have been conducted in education, but for varied purposes, implementing an assortment of CBR structures, and collecting data on disparate concerns using diverse methods. This makes comparisons and the identification of consistent patterns across studies problematic, leaving a patchwork of incomplete knowledge about the feasibility and effectiveness of CBR and factors that might constitute best practice in doctoral programs.

Stocking and Cutforth (2006), for example, described graduate-level CBR experiences elected by doctoral and master's students in the College of Education at the University of Denver. Challenges faced by faculty who teach such courses included finding disciplinary/content connections, building CBR into courses/curricula, ensuring student readiness for the demands of $\mathrm{CBR}$, and 
structuring the CBR experience given time and logistical parameters/constraints (no data were provided on student or community impact). Tinkler (2010) also conducted two CBR projects in education at the University of Denver, one for her doctoral dissertation. She structured data analysis around a framework that includes four goals: community engagement, collaboration, knowledge creation, and change. Results suggested that the radical model of CBR described by Stoecker (2003) is a more effective approach than the mainstream model, if the goal is to foster social action leading to social justice.

In addition, Puma, Bennett, Cutforth, Tombari, and Stein (2009) employed case study methodology to examine promising practices and shortcomings of a large CBR project in a $\mathrm{PhD}$ program in education at the University of Denver conducted by two graduate students and a faculty member who partnered with a community organization and an external funder. Most of their lessons learned focused on issues of research design and collaboration with community partners; they caution that graduate students who participate in CBR must possess the research skills needed to successfully complete the projects developed. Tinkler (2010) made a related point, noting that successfully finishing a project not only includes the ability to actually conduct technical aspects of the research, but also a host of interaction and interpersonal skills that enable mutuality amongst partners in the project, especially demonstrated when university faculty and students seek and value needs as perceived and expressed by community partners. Such mutuality leads to co-creation of the project as well as co-discovery of knowledge. In other words, through participation in CBR, student and faculty perceptions that frame community partners as recipients of academic expertise can evolve into attitudes that validate community partner experience as essential to expanding knowledge. This shift in attitude is itself a skill that can be developed through participating in CBR (see Tinkler, 2010).

CBR studies also have been conducted in educational leadership doctoral programs. Specifically, Stevahn (2014) and colleagues discovered factors that facilitated or frustrated successful CBR as perceived by first-year doctoral students in the Educational Leadership program at Seattle University. Results emerged from content analysis of thick description in year-long written logs documenting student CBR actions, reflections, and learnings. Overall, the findings suggested that students, faculty, and community partners engaged in cooperative CBR "should constantly seek clarity (of purpose, procedures, products), get concrete (use templates), communicate (frequently, respectfully, personally, mutually), and confront conflict (constructively)" (p. 32). Case (2014) also examined issues pertaining to the implementation of CBR in an educational leadership doctorate at the University of Hartford. Findings revealed factors central to successful CBR, including institutional and program readiness, research rigor, relationship building, assessment of CBR products, and collaborative decision making.

Although an increasing number of researchers now are focusing on the use of CBR in graduate coursework, many gaps remain in our understanding. As with other forms of service-learning, little is known regarding the types of specific practices and conditions that help produce desired results, or why CBR goals are actually met (Bringle, Clayton, \& Hatcher, 2013). Additional research also is needed on the attainment of student learning outcomes, ranging from intellectual development to civic learning, personal development, and intercultural competence. Toward providing information that more comprehensively informs CBR in the educational leadership doctorate, we systematically sought input from our doctoral students across three consecutive cohorts that each conducted cooperative CBR during their first year in the program. Specifically, we sought to better understand the effects of integrating CBR into the education doctorate on students' (a) attitudes toward and competence in conducting CBR, (b) preparation for dissertation research, (c) cooperative/collaborative skills, (d) project management leadership skills, and (e) learning how to work with the community to enact broad-based change. 


\section{Method}

\section{Context and Design}

This study employed a mixed-methods developmental case study design. Three separate cohorts (cases) conducted CBR, each during its first year (fall, winter, spring) in the doctoral program. Cohort 35 entered the program in 2010, Cohort 36 in 2012, and Cohort 37 in 2013 (the program did not admit a cohort in 2011, so these represent three consecutive cohorts). The first year of leadership studies engaged students in a year-long course focused on "leader as self" in which they considered and further developed personal leadership qualities, characteristics, strengths, and skill sets. Students also concurrently enrolled in a series of research methods courses across that year; that is, general methods in fall, quantitative in winter, and qualitative in spring. In addition, some students also began coursework in their chosen area of professional specialization - that is, adult-postsecondary-higher education; superintendant, principal, or program administrator; public and nonprofit leadership; spiritual leadership; or nursing leadership — whereas some began specialization courses in their second year.

In all cases, CBR was integrated into first-year doctoral studies, although with subsequent adjustments each year to developmentally enact lessons learned as shown in Table 1. Ultimately, Cohort 35 conducted CBR as part of a required "leader as self" year-long course, whereas. Cohorts 36 and 37 each conducted CBR in a separate year-long course solely devoted to that purpose. Cohort 35 formed three CBR teams, each mentored by one of three instructors who teamtaught the course. Cohort 36 formed four CBR teams, mentored by two instructors who teamtaught the course. Cohort 37 formed five CBR teams, mentored by one instructor who taught the course. In all cohorts, students self-selected their CBR team, each working with a different CBO focused on its particular initiative for social change. It is noteworthy that CBR was required of all doctoral students in these three cohorts, in contrast to other higher education CBR implementations in which a select few students work with faculty to conduct CBR, or in which students voluntarily choose CBR as an option among other alternatives to fulfill course requirements.

Table 1. CBR in Seattle University's Educational Leadership Doctoral Program

\begin{tabular}{llcl}
\hline Description & \multicolumn{1}{c}{$\begin{array}{c}\text { Cohort 35 } \\
\text { Academic Year } \\
2010-2011\end{array}$} & $\begin{array}{c}\text { Cohort 36 } \\
\text { Academic Year } \\
2012-2013\end{array}$ & $\begin{array}{c}\text { Cohort 37 } \\
\text { Academic Year } \\
\text { 2013-2014 }\end{array}$ \\
\hline Participants & \multicolumn{1}{c}{$n=18$} & \multicolumn{1}{c}{$n=14$} & $n=15$ \\
\hline Duration & $\begin{array}{l}\text { Program Year 1 } \\
\text { (Fall, Winter, Spring) }\end{array}$ & $\begin{array}{c}\text { Program Year 1 } \\
\text { (Fall, Winter, Spring) }\end{array}$ & $\begin{array}{c}\text { Program Year 1 } \\
\text { (Fall, Winter, Spring) }\end{array}$ \\
\hline Curriculum & $\begin{array}{l}\text { CBR integrated into } \\
\text { the first-year leadership } \\
\text { course on enhancing } \\
\text { personal leadership skills }\end{array}$ & $\begin{array}{l}\text { CBR integrated into } \\
\text { the program through a } \\
\text { for applied practice. }\end{array}$ & $\begin{array}{l}\text { CBR integrated into } \\
\text { the program through a }\end{array}$ \\
& $\begin{array}{l}\text { first-year course } \\
\text { specifically for CBR. }\end{array}$ & $\begin{array}{l}\text { separate year-long } \\
\text { first-year course } \\
\text { specifically for CBR. }\end{array}$ \\
\hline Instructors & $\begin{array}{l}\text { Team-taught course; } \\
\text { three instructors mentor- }\end{array}$ & $\begin{array}{l}\text { Team-taught course; } \\
\text { two instructors mentor- }\end{array}$ & $\begin{array}{l}\text { One instructor mentoring } \\
\text { five CBR teams. }\end{array}$ \\
& ing three CBR teams. & ing four CBR teams. & \\
\hline
\end{tabular}




\begin{tabular}{|c|c|c|c|}
\hline Description & $\begin{array}{c}\text { Cohort 35 } \\
\text { Academic Year } \\
\text { 2010-2011 }\end{array}$ & $\begin{array}{c}\text { Cohort 36 } \\
\text { Academic Year } \\
\text { 2012-2013 } \\
\end{array}$ & $\begin{array}{c}\text { Cohort } 37 \\
\text { Academic Year } \\
\text { 2013-2014 }\end{array}$ \\
\hline $\begin{array}{l}\text { Community- } \\
\text { Based Organ- } \\
\text { izations } \\
(\mathrm{CBOs})\end{array}$ & $\begin{array}{l}\text { Three CBOs serving: } \\
\text { (a) second-language } \\
\text { learners, (b) urban teen } \\
\text { girl leadership, (c) col- } \\
\text { lege admission/retention } \\
\text { of Latino/a youth. }\end{array}$ & $\begin{array}{l}\text { Four CBOs serving: } \\
\text { (a) retired adults in urban } \\
\text { low-income housing, } \\
\text { (b) Vietnamese cultural } \\
\text { center, (c) university- } \\
\text { based community- } \\
\text { engagement initiative, } \\
\text { (d) evaluation of a grad- } \\
\text { uate program focused on } \\
\text { social justice. }\end{array}$ & $\begin{array}{l}\text { Five CBOs (three con- } \\
\text { tinuing from the prior } \\
\text { year) serving: (a) retired } \\
\text { adults in urban } \\
\text { low-income housing, } \\
\text { (b) Vietnamese cultural } \\
\text { center, (c) university- } \\
\text { based community- } \\
\text { engagement initiative, } \\
\text { (d) low-income urban } \\
\text { families, (e) minority } \\
\text { youth to advance educa- } \\
\text { tional achievement. }\end{array}$ \\
\hline Procedures & $\begin{array}{l}\text {-Instructors obtained } \\
\text { CBOs prior to start of the } \\
\text { course. } \\
\text { - CBOs presented needs } \\
\text { and focus at the first } \\
\text { class session. } \\
\text { - Students self-selected } \\
\text { CBR team/project with } \\
\text { one CBO partner. } \\
\text { - Class time within each } \\
\text { day-long session was } \\
\text { devoted to CBR (2.5- } \\
\text { hours each afternoon } \\
\text { across nine class sessions } \\
\text { for } 22.5 \text { hours total). }\end{array}$ & $\begin{array}{l}\text {-Instructors obtained } \\
\text { CBOs prior to start of } \\
\text { the course and gave stu- } \\
\text { dents information on } \\
\text { CBO needs/focus.. } \\
\text {-Students self-selected } \\
\text { CBR team/project with } \\
\text { one CBO partner. } \\
\text {-Class entirely devoted } \\
\text { to CBR; teams worked } \\
\text { on CBR at each class } \\
\text { session ( } 3 \text { hours } 20 \\
\text { minutes across nine ses- } \\
\text { sions for } 30 \text { hours total). } \\
\text {-Met irregularly as need- } \\
\text { ed with CBOs across the } \\
\text { year. }\end{array}$ & $\begin{array}{l}\text {-Instructors obtained } \\
\text { CBOs prior to the start of } \\
\text { the course. } \\
\text {-CBOs presented needs } \\
\text { and focus at the first } \\
\text { class session. } \\
\text {-Students self-selected } \\
\text { CBR team/project with } \\
\text { one CBO partner. } \\
\text {-Class entirely devoted } \\
\text { to CBR; teams worked } \\
\text { on CBR at each class } \\
\text { session ( } 3 \text { hours } 20 \\
\text { minutes across nine ses- } \\
\text { sions for } 30 \text { hours total). } \\
\text {-Met regularly with } \\
\text { CBOs across the year. }\end{array}$ \\
\hline $\begin{array}{l}\text { Lessons } \\
\text { learned and } \\
\text { developmen- } \\
\text { tally imple- } \\
\text { mented each } \\
\text { year }\end{array}$ & $\begin{array}{l}\text {-Verbal agreements with } \\
\text { CBOs; learned the im- } \\
\text { portance of establishing } \\
\text { clear written agreements } \\
\text { with CBOs about the } \\
\text { scope of each project. } \\
\text {-General } \\
\text { processing/reflection; } \\
\text { learned the importance } \\
\text { of focused/precise indi- } \\
\text { vidual and team pro- } \\
\text { cessing/reflection. }\end{array}$ & $\begin{array}{l}\text { - Required a written } \\
\text { Memorandum of Under- } \\
\text { standing (MOU) be- } \\
\text { tween each CBR team } \\
\text { and CBO partner. } \\
\text {-Systematically integrat- } \\
\text { ed focused/precise team } \\
\text { processing/ reflection } \\
\text { into each class session, } \\
\text { especially on CBR skills } \\
\text { useful for future disserta- } \\
\text { tion research. } \\
\text {-Learned importance of } \\
\text { regular communication } \\
\text { and meetings between } \\
\text { CBR teams and CBOs. }\end{array}$ & $\begin{array}{l}\text {-Increased time during } \\
\text { class sessions for teams } \\
\text { to work on CBR tasks. } \\
\text {-CBR teams met more } \\
\text { regularly with CBOs. } \\
\text {-Increased time for pro- } \\
\text { cessing/reflection on } \\
\text { CBR progress and team } \\
\text { functioning, community } \\
\text { issues/needs, communi- } \\
\text { cation with CBOs, and } \\
\text { connections to future } \\
\text { dissertation research. }\end{array}$ \\
\hline
\end{tabular}


All CBOs that partnered with our students worked with low-income inner-city residents to address their health and human services needs. Examples of projects co-created by CBO partners and CBR student teams included:

- Collaborating with an urban residence serving older adults of low-income to develop a survey instrument and focus group interview for data collection that would reveal residents' unmet needs, interests, and skills. This culminated with a written report and presentation to residents, staff, and directors, who then used the results for planning positive change.

- Conducting all phases of a community needs assessment in conjunction with a CBO that provided basic services, advocacy, and education to facilitate individuals and families of low-income in moving from poverty to self-sufficiency. This included instrument design, data collection and analysis, and preparation of a detailed final report, including recommendations for action.

- Partnering with a CBO that provided support for Vietnamese immigrants seeking data to use in support of the development of a new community cultural center. This included mapping immigrants' home locations, analyzing migration patterns, and extracting data from the United States Census website to prepare and present a final report to CBO directors toward furthering plans for the center.

Regardless of how CBR was integrated into first-year doctoral studies across the cohorts, all students were instructed to approach CBR as an authentic lived experience to hone leadership skills, learn research skills in preparation for the dissertation, and refine interpersonal and cultural competence skills necessary for effective professional practice. All cohorts also engaged in reflection on what was working well, possible useful adjustments, and how various skill sets were developing through first-hand practice. Student feedback enabled instructors to learn valuable lessons that led to developmentally enhancing procedures/implementations each subsequent year. Lessons learned resulted in (a) increased, ongoing, focused, and precise individual and team reflections on effectiveness; (b) a formal written Memorandum of Understanding (MOU) specifying mutual agreements between each CBR team and its $\mathrm{CBO}$; and (c) regular meetings throughout the year with CBOs for ongoing communication.

\section{Participants}

Students in each of the three participating cohorts represented a mix of men and women, ethnic/cultural backgrounds, and professional specializations. Basic demographic information is summarized in Table 2. All students had earned master's degrees, ranged in age from late 20s to early $60 \mathrm{~s}$ (most in their 30s and 40s), and worked either full-time or part-time across an array of professional contexts, including P-12 education/administration, student development in higher education, nursing/health, theology/ministry, or government/nonprofit leadership (only a few were full-time students). Most also lived in or near the city of Seattle, although a few in each cohort traveled longer distances (approximately 1 to 2 hours) to campus for coursework, which included conducting CBR (all CBOs were in the vicinity surrounding the university).

Seattle University is a private Jesuit 4-year institution of higher education with a student population of approximately 7,500 (about 4,500 undergraduate, 1,000 law, and 2,000 graduate students). The Educational Leadership EdD program is comprised of about 60 to 70 students total in any given year and is housed in the College of Education that has approximately 550 graduate students total across 11 different programs (all but the EdD at the master's level). Approximately $60 \%$ of Seattle University's entire student population is Caucasian and $40 \%$ represents an array of diverse ethnic/cultural identities. It is noteworthy that the ethnic/cultural diversity within each of the three cohorts participating in this study, as shown in Table 2, overall reflected the student di- 
versity at Seattle University. The university is located in an urban setting-within blocks from downtown Seattle and immediately adjacent to medical centers, small businesses, a low-income housing development, single-family dwellings, and several Seattle Public Schools (an elementary, middle, and high school). The educational leadership EdD degree was the only doctorate offered at Seattle University when Cohort 35 matriculated in 2010; subsequently, professional doctorates in both nursing and divinity also were instituted.

Table 2. Demographic information

\begin{tabular}{lccc}
\hline \multicolumn{1}{c}{ Categories } & $\begin{array}{c}\text { Cohort 35 } \\
(n=18)\end{array}$ & $\begin{array}{c}\text { Cohort 36 } \\
(n=14)\end{array}$ & $\begin{array}{c}\text { Cohort 37 } \\
(n=15)\end{array}$ \\
\hline Gender & & & \\
Men & $5(27.7 \%)$ & $3(21.4 \%)$ & $7(46.6 \%)$ \\
$\quad$ Women & $13(72.2 \%)$ & $11(78.6 \%)$ & $8(53.3 \%)$ \\
Ethnic/cultural background & & & \\
$\quad$ Caucasian & $11(61.1 \%)$ & $8(57.1 \%)$ & $9(60 \%)$ \\
$\quad$ Diverse ethnic/racial identities & $7(38.8 \%)$ & $6(42.8 \%)$ & $6(40 \%)$ \\
Leadership Specialization & & & $12(80 \%)$ \\
$\quad$ Adult/Postsecondary/Higher Education & $8(44.4 \%)$ & $5(36 \%)$ & $3(20 \%)$ \\
$\quad$ Superintendant / Principal / Program Admin & $6(33.3 \%)$ & $4(28 \%)$ & 0 \\
Public/Nonprofit; Spiritual; Nursing; Other & $4(22.2 \%)$ & $5(36 \%)$ & 0 \\
\hline
\end{tabular}

Note. Categories intentionally are broad to protect participant identities.

\section{Data Collection and Analysis}

Three instruments were used to collect data. Various cohorts responded to each as summarized in Table 3. The sections that follow describe each instrument and corresponding data analysis.

Table 3. Overview of data collection across cohorts and instruments

\begin{tabular}{lccc}
\hline \multicolumn{1}{c}{ Instrument } & $\begin{array}{c}\text { Cohort 35 } \\
(n=18)\end{array}$ & $\begin{array}{c}\text { Cohort 36 } \\
(n=14)\end{array}$ & $\begin{array}{c}\text { Cohort 37 } \\
(n=15)\end{array}$ \\
\hline CBR Process-Product Questionnaire & $\checkmark$ & $\checkmark$ & $\checkmark$ \\
CBR Reflection Survey & & $\checkmark$ & $\checkmark$ \\
CBR Self-Assessment Instrument & & & $\checkmark$ \\
\hline
\end{tabular}

\section{CBR Process-Product Questionnaire}

We adapted our instrument from the Postdecision Questionnaire (Johnson \& F. Johnson, 2017) that has established validity and reliability from its long history of repeated use to assess perceived effectiveness of cooperative decision making. Students in Cohorts 35, 36, and 37 all responded to this instrument in class at the end of the school year upon completion of their CBR projects. The first eight items are quantitative semantic differentials that pertain to various dimensions of effective teamwork. Responses are scaled from 1 through 9 (for example, from not present/satisfied to completely present/satisfied). Comparisons across all three cohorts were analyzed using a one-way ANOVA (results reported in Table 4). The final ninth item on the instrument asked students to write three words to describe their CBR experience. Qualitative responses were coded by three independent readers as positive, negative, or neither positive/negative, and then compared for agreement, which was nearly congruent. Through discussion, consensus was reached among the readers on all classifications (results reported in Table 5). 


\section{CBR Reflection Survey}

We developed this instrument to obtain more in-depth, open-ended, qualitative feedback from our students on their CBR experience in Seattle University's educational leadership doctorate. This survey consists of nine items that probe (a) feelings about the final CBR team report/product, (b) understanding about research, (c) contributions to CBR team success, (d) changes for future improvement, (e) faculty/instructor helpfulness, (f) how faculty/instructors could further assist, (g) lessons learned from engaging with the $\mathrm{CBO},(\mathrm{h})$ advice for future cohorts who might conduct $\mathrm{CBR}$, and (i) any additional comments. Students in Cohorts 36 and 37 responded to this instrument in class at the end of the school year. Three independent readers conducted a content analysis in which they separately identified recurring input provided by students in the two responding cohorts. Themes from each cohort were compared across all readers whose analyses were nearly identical, although sometimes different phrases were used to describe themes that were conceptually similar. In the few instances where substantive differences in themes emerged, readers shared and discussed their rationales for coding, reached agreement on similar themes within each cohort, then compared and reached consensus on one final set of overarching themes applicable to both cohorts. All themes strongly captured the essence of responses from both cohorts and, therefore, were combined for display (results reported in Table 6).

\section{CBR Self-Assessment Instrument}

We adapted the Community Engaged Competencies Self-Assessment (Jameson, Jaeger, Clayton, \& Bringle, 2012) that was developed for use with faculty in the EDGES program at the University of North Carolina. Our adapted instrument included 22 items total that asked students to rate themselves on various competencies related to their use of CBR. Response choices were scaled as $1=$ None, $2=$ Minimal, $3=$ Basic, $4=$ Intermediate, $5=$ Proficient, $6=$ Advanced . Each item also included not applicable as a response option, however this was eliminated in the final analysis because students never marked it. Our primary modification was a change in terminology from "community engaged scholarship" to "community-based research." We also added several items dealing with Institutional Review Board (IRB) procedures, development and use of a Memorandum of Understanding (MOU), and knowledge of basic inquiry/research skills. Finally, we eliminated several items appropriate for faculty but not relevant for doctoral students. This instrument was administered in class at the end of the school year to Cohort 37 only; once as a retrospective pretest, then again as a posttest given separate and apart from the pretest. Differences between pretest and posttest means were analyzed by computing dependent $t$ tests (results reported in Table 7). This CBR competency instrument and retrospective pretest method have been used in other studies - for example, to examine outcomes from implementing the EDGES Program - to account for potential response shift bias that occurs when individuals incorrectly report their own competency levels prior to participation in a course or program (Jameson et al., 2012).

\section{Results}

\section{CBR Process-Product Questionnaire}

Cohorts 35, 36, and 37 responded to the CBR Process-Product Questionnaire that assessed the extent to which students perceived mutual interaction, influence, responsibility, satisfaction, and learning through conducting their CBR team project. Table 4 reports quantitative results, showing consistently high means across all cohorts and no statistically significant differences among them.

Table 5 reports results from the qualitative item on the questionnaire, showing that the words students used to describe their CBR experience overwhelmingly were positive. This suggests that students' attitudes and dispositions toward their CBR experience generally were affirming - i.e., students valued CBR and viewed conducting it as beneficial. However, words categorized as neg- 
ative, although few overall, do reveal a certain level of interpersonal conflict that regularly occurred in teams across all cohorts while conducting CBR across the entire school year. This occurred more intensely in some CBR teams than others (see Stevahn, 2014 for a more in-depth analysis of conflict that Cohort 35 students experienced while conducting CBR).

Table 4. CBR process-product questionnaire: One-way ANOVA posttest comparison

\begin{tabular}{|c|c|c|c|c|c|c|c|c|c|}
\hline \multirow{2}{*}{\multicolumn{2}{|c|}{ Item }} & \multicolumn{2}{|c|}{$\begin{array}{c}{\text { Cohort } 35^{\mathrm{a}}}^{(n=18)}\end{array}$} & \multicolumn{2}{|c|}{$\begin{array}{c}\text { Cohort } 36 \\
(n=14)\end{array}$} & \multicolumn{2}{|c|}{$\begin{array}{l}\text { Cohort } 37 \\
(n=15)\end{array}$} & \multirow[b]{2}{*}{$F$} & \multirow[b]{2}{*}{$p$ value } \\
\hline & & $M$ & $S D$ & $M$ & $S D$ & $M$ & $S D$ & & \\
\hline 1. & $\begin{array}{l}\text { Teammates } \\
\text { listened to } \\
\text { your ideas. }\end{array}$ & 8.00 & (1.188) & 7.71 & (2.164) & 7.77 & (1.033) & .187 & .830 \\
\hline 2. & $\begin{array}{l}\text { Teammates } \\
\text { understood } \\
\text { your ideas. }\end{array}$ & 7.89 & (1.278) & 7.79 & (1.929) & 7.80 & $(1.056)$ & .166 & .848 \\
\hline 3. & $\begin{array}{l}\text { Influence you } \\
\text { had on team } \\
\text { decisions. }\end{array}$ & 7.50 & $(1.150)$ & 7.43 & $(2.065)$ & 7.47 & (1.302) & .009 & .991 \\
\hline 4. & $\begin{array}{l}\text { Responsibil- } \\
\text { ity you feel } \\
\text { for team } \\
\text { decisions. }\end{array}$ & 7.00 & $(1.782)$ & 7.86 & $(1.231)$ & 7.87 & (.990) & 2.077 & .137 \\
\hline 5. & $\begin{array}{l}\text { Influence you } \\
\text { had on team's } \\
\text { final report. }\end{array}$ & 7.22 & (1.833) & 7.93 & (1.328) & 8.00 & $(.845)$ & 1.508 & .233 \\
\hline 6. & $\begin{array}{l}\text { Responsibil- } \\
\text { ity you feel } \\
\text { for team's } \\
\text { final report. }\end{array}$ & 7.50 & $(1.823)$ & 8.07 & $(1.072)$ & 8.20 & $(.561)$ & 1.346 & .271 \\
\hline 7. & $\begin{array}{l}\text { Satisfied with } \\
\text { team's } \\
\text { overall } \\
\text { performance. }\end{array}$ & 7.67 & (1.815) & 7.86 & (1.167) & 7.60 & (1.298) & .117 & .890 \\
\hline 8. & $\begin{array}{l}\text { How much } \\
\text { you learned } \\
\text { about the } \\
\text { research } \\
\text { questions } \\
\text { your team } \\
\text { investigated. }\end{array}$ & 7.37 & (1.614) & 8.14 & $(.864)$ & 7.87 & (1.125) & 1.442 & .247 \\
\hline
\end{tabular}

Note. Semantic differential scale: 1 (low/none/never) through 9 (high/lots/completely).

${ }^{\mathrm{a}}$ From Stevahn (2014). 
Table 5. CBR process-product questionnaire: Qualitative posttest responses

\begin{tabular}{|c|c|c|c|}
\hline Words & $\begin{array}{l}\text { Cohort } 35^{\mathrm{a}} \\
(n=18)\end{array}$ & $\begin{array}{c}\text { Cohort } 36 \\
(n=14)\end{array}$ & $\begin{array}{c}\text { Cohort } 37 \\
(n=15)\end{array}$ \\
\hline Positive & $\begin{array}{l}\text { Challenging (4) } \\
\text { Chemistry } \\
\text { Collaboration } \\
\text { Collaborative (4) } \\
\text { Collective } \\
\text { Communication } \\
\text { Community } \\
\text { Educational } \\
\text { Empowering } \\
\text { Evolving } \\
\text { Engaging } \\
\text { Enlightening (2) } \\
\text { Focused } \\
\text { Fulfilling } \\
\text { Fun } \\
\text { Growth (2) } \\
\text { Humor } \\
\text { Informative (3) } \\
\text { Insightful (2) } \\
\text { Learning experience } \\
\text { Learningful } \\
\text { Patience } \\
\text { Positive (3) } \\
\text { Profound } \\
\text { Rewarding } \\
\text { Synergy } \\
\text { Team effort } \\
\text { Triumphant } \\
\text { Valuable } \\
\text { Worthwhile }\end{array}$ & $\begin{array}{l}\text { Adequate } \\
\text { Awesome } \\
\text { Beneficial } \\
\text { Challenging (3) } \\
\text { Collaborative (2) } \\
\text { Communication } \\
\text { Cooperative } \\
\text { Easy } \\
\text { Educational } \\
\text { Enjoyable } \\
\text { Enriching } \\
\text { Experiential } \\
\text { Eye-opening (2) } \\
\text { Fascinating } \\
\text { Focused (2) } \\
\text { Friendship } \\
\text { Hands-on (2) } \\
\text { Important } \\
\text { Informative } \\
\text { Instrumental } \\
\text { Interesting } \\
\text { Learning (2) } \\
\text { Meaningful } \\
\text { Patience } \\
\text { Practice } \\
\text { Proactive } \\
\text { Research excited } \\
\text { about } \\
\text { Successful } \\
\text { Teamwork } \\
\text { Wonderful } \\
\text { Worthwhile }\end{array}$ & $\begin{array}{l}\text { Challenged } \\
\text { Challenging (2) } \\
\text { Collaborate } \\
\text { Collaborative } \\
\text { Communication } \\
\text { Compromise } \\
\text { Fun } \\
\text { Gaining } \\
\text { Gratifying (2) } \\
\text { Growing } \\
\text { Educational } \\
\text { Illuminating } \\
\text { Hard working } \\
\text { Heart warming } \\
\text { Helpful } \\
\text { Innovative } \\
\text { Inspiring } \\
\text { Interesting (3) } \\
\text { Listen } \\
\text { Meaningful } \\
\text { Persevere } \\
\text { Positive } \\
\text { Privileged } \\
\text { Relieved } \\
\text { Rewarding (2) } \\
\text { Smart } \\
\text { Stretching } \\
\text { Tantalizing } \\
\text { Team centered } \\
\text { Thankful } \\
\text { Trust }\end{array}$ \\
\hline Negative & $\begin{array}{l}\text { Difficult } \\
\text { Disengaged } \\
\text { Frustrating } \\
\text { Long } \\
\text { Taxing } \\
\text { Troubling } \\
\text { Trying } \\
\text { Uncommunicative } \\
\text { Unfortunate }\end{array}$ & $\begin{array}{l}\text { Frustrating } \\
\text { Frustrating originally }\end{array}$ & $\begin{array}{l}\text { Arduous } \\
\text { Frustrating (3) } \\
\text { Exhausting } \\
\text { Incomplete/rushed } \\
\text { Stressful } \\
\text { Time consuming }\end{array}$ \\
\hline $\begin{array}{l}\text { Neither } \\
\text { positive/negative }\end{array}$ & Research & $\begin{array}{l}\text { Beginning level } \\
\text { Research }\end{array}$ & Rollercoaster \\
\hline
\end{tabular}

Note. Words are listed alphabetically; numbers in parentheses indicate frequency $>1$.

${ }^{a}$ From Stevahn (2014). 


\section{CBR Reflection Survey}

Cohorts 36 and 37 responded to the CBR Reflection Survey that qualitatively assessed student perceptions of their CBR experience through open-ended items that probed feelings, understandings, lessons learned, and suggestions for improvement. Table 6 reveals three major themes focused on effective practice, each further elaborated by descriptive behaviors/activities repeatedly noted by students across both cohorts as important to successful CBR. These themes point to the importance of team, technical, and management skills for successfully conducting CBR as group projects.

Table 6. CBR reflection survey: Qualitative posttest themes

\begin{tabular}{ll}
\hline Theme/Factor & Descriptive behaviors/activities for effective practice \\
\hline Team skills & - Provide clear and ongoing communication \\
& - Contribute individual strengths to the team \\
& - Support and trust teammates \\
- Use collaborative/cooperative skills for effective teamwork \\
Technical skills & - Use constructive conflict skills to deal with disagreements \\
& - Dearly frame/define research questions \\
& - Deal with data collection challenges/surprises \\
& - Accurately interpret findings \\
& - Meport results to CBOs in professional/user-friendly formats \\
& - Understand the purpose of the IRB and submission process \\
- Establish clear expectations/boundaries/MOUs with CBOs & \\
- Establish expectations/roles/tasks among teammates \\
- Define/Limit the scope of the project \\
- Establish a timeline/calendar with benchmarks \\
- Start early; establish a clear plan from the beginning \\
- Manage/Pace the project \\
- Exercise flexibility; make adjustments when warranted
\end{tabular}

Note. Themes emerged from separate analyses of Cohort $36(n=14)$ and Cohort $37(n=15)$ data, were similar across cohorts, and therefore are combined for reporting.

\section{CBR Self-Assessment Instrument}

Cohort 37 responded to the CBR Self-Assessment Instrument that quantitatively assessed student perceptions of various competencies related to their knowledge and application of CBR, ability to collaborate with peers and community partners, ability to submit to the IRB, ability to prepare MOUs, knowledge and application of foundational inquiry/research skills, and knowledge of key research issues relevant to completing a dissertation later in their doctoral program. Table 7 reports results showing statistically significant differences between the retrospective pretest-posttest comparisons on nearly all items. Note that the least amount of growth occurred in Items 9, 10, and 12 that focused respectively on (a) working with diverse communities, (b) negotiating across academic/community contexts, and (c) collaborating with community partners for capacity building. This may be due to the fact that students rated these three items most highly on the retrospective pretest (i.e., students felt competent in these areas prior to conducting CBR), thereby greatly limiting the possibility of reporting improvement on the posttest. Also, although means in Items 10 and 12 were not significantly different, they are approaching significance at the .05 level. 
Table 7. CBR self-assessment instrument: Retrospective pretest-posttest comparison

\begin{tabular}{|c|c|c|c|c|c|c|c|}
\hline \multirow[b]{2}{*}{ Item } & \multirow[b]{2}{*}{$n$} & \multicolumn{2}{|c|}{ Pretest } & \multicolumn{2}{|c|}{ Posttest } & \multirow[b]{2}{*}{$t$} & \multirow[b]{2}{*}{$p$ value } \\
\hline & & $M$ & $S D$ & $M$ & $S D$ & & \\
\hline $\begin{array}{l}\text { 1. Understand the } \\
\text { concept of CBR. }\end{array}$ & 15 & 2.27 & $(.961)$ & 4.80 & $(.561)$ & -9.906 & $.000 * * *$ \\
\hline $\begin{array}{l}\text { 2. Convey to others the } \\
\text { meaning of CBR. }\end{array}$ & 15 & 1.87 & $(.640)$ & 4.80 & $(.775)$ & -11.820 & $.000 * * *$ \\
\hline $\begin{array}{l}\text { 3. Know histo- } \\
\text { ry/literature of CBR. }\end{array}$ & 14 & 1.43 & $(.514)$ & 3.64 & (1.008) & -9.282 & $.000 * * *$ \\
\hline $\begin{array}{l}\text { 4. Understand contribu- } \\
\text { tors to community } \\
\text { issues. }\end{array}$ & 15 & 3.07 & $(1.335)$ & 4.60 & $(1.056)$ & -5.602 & $.000 * * *$ \\
\hline $\begin{array}{l}\text { 5. Skills for social } \\
\text { change. }\end{array}$ & 15 & 3.40 & $(1.242)$ & 4.73 & $(.884)$ & -4.641 & $.000 * * *$ \\
\hline $\begin{array}{l}\text { 6. Commitment to } \\
\text { fostering social } \\
\text { change. }\end{array}$ & 15 & 3.67 & (1.397) & 5.00 & $(.926)$ & -4.183 & $.001 * * *$ \\
\hline $\begin{array}{l}\text { 7. Know principles of } \\
\text { CBR. }\end{array}$ & 15 & 2.00 & $(1.000)$ & 4.47 & $(.834)$ & -9.012 & $.000 * * *$ \\
\hline $\begin{array}{l}\text { 8. Skill in applying } \\
\text { principles of CBR. }\end{array}$ & 15 & 1.87 & $(.915)$ & 4.20 & $(1.082)$ & -8.635 & $.000 * * *$ \\
\hline $\begin{array}{l}\text { 9. Work effectively with } \\
\text { diverse communities. }\end{array}$ & 14 & 4.71 & (1.139) & 5.07 & (.997) & -2.687 & $.019 *$ \\
\hline $\begin{array}{l}\text { 10. Negotiate across } \\
\text { community-academic } \\
\text { groups/contexts. }\end{array}$ & 14 & 4.14 & $(1.562)$ & 4.79 & $(1.051)$ & -1.979 & .069 \\
\hline $\begin{array}{l}\text { 11. Collaborate with } \\
\text { community partners } \\
\text { for useful CBR. }\end{array}$ & 14 & 2.36 & (1.008) & 4.86 & (1.009) & -6.679 & $.000 * * *$ \\
\hline $\begin{array}{l}\text { 12. Collaborate with } \\
\text { community partners } \\
\text { for capacity building. }\end{array}$ & 14 & 3.86 & $(1.562)$ & 4.64 & $(1.227)$ & -1.924 & .077 \\
\hline $\begin{array}{l}\text { 13. Share learning about } \\
\text { CBR with others. }\end{array}$ & 14 & 2.21 & $(1.251)$ & 5.15 & $(.770)$ & -7.346 & $.000 * * *$ \\
\hline $\begin{array}{l}\text { 14. Collaborate with other } \\
\text { students/peers in CBR. }\end{array}$ & 14 & 3.29 & $(1.326)$ & 5.29 & $(.726)$ & -4.497 & $.001 * * *$ \\
\hline $\begin{array}{l}\text { 15. Understand conditions } \\
\text { needed for strong } \\
\text { partnerships in CBR. }\end{array}$ & 14 & 2.21 & $(.975)$ & 4.93 & $(.730)$ & -7.659 & $.000 * * *$ \\
\hline $\begin{array}{l}\text { 16. Skills in establishing, } \\
\text { maintaining, and } \\
\text { strengthening } \\
\text { partnerships in CBR. }\end{array}$ & 14 & 2.21 & $(1.122)$ & 4.50 & $(.855)$ & -7.101 & $.000 * * *$ \\
\hline $\begin{array}{l}\text { 17. Understanding IRB } \\
\text { procedures. }\end{array}$ & 14 & 1.50 & $(1.082)$ & 4.14 & $(1.231)$ & -6.382 & $.000 * * *$ \\
\hline $\begin{array}{l}\text { 18. Ability to prepare IRB } \\
\text { forms for approval. }\end{array}$ & 14 & 1.50 & $(1.60)$ & 3.93 & (1.141) & -5.844 & $.000 * * *$ \\
\hline 19. Collaboratively & 14 & 1.79 & $(.802)$ & 4.71 & $(.825)$ & -10.225 & $.000 * * *$ \\
\hline
\end{tabular}
prepare an MOU to guide CBR. 


\begin{tabular}{|c|c|c|c|c|c|c|c|}
\hline \multirow[b]{2}{*}{ Item } & \multirow[b]{2}{*}{$n$} & \multicolumn{2}{|c|}{ Pretest } & \multicolumn{2}{|c|}{ Posttest } & \multirow[b]{2}{*}{$t$} & \multirow[b]{2}{*}{$p$ value } \\
\hline & & $M$ & $S D$ & $M$ & $S D$ & & \\
\hline $\begin{array}{l}\text { 20. Understand basic } \\
\text { inquiry/research skills. }\end{array}$ & 14 & 1.64 & $\begin{array}{l}(1.082) \\
\end{array}$ & 3.93 & $(1.072)$ & -7.101 & $.000 * * *$ \\
\hline $\begin{array}{l}\text { 21. Apply basic } \\
\text { inquiry/research skills } \\
\text { to generate CBR. }\end{array}$ & 14 & 1.43 & $(.938)$ & 3.93 & (1.141) & -6.957 & $.000 * * *$ \\
\hline $\begin{array}{l}\text { 22. Understand key } \\
\text { research issues } \\
\text { relevant to completing } \\
\text { a dissertation. }\end{array}$ & 14 & 2.36 & $(.929)$ & 4.36 & $(.633)$ & -8.532 & $.000 * * *$ \\
\hline
\end{tabular}

Note. Scale: $1=$ None, $2=$ Minimal, $3=$ Basic, $4=$ Intermediate, $5=$ Proficient, $6=$ Advanced .

Responses from Cohort 37 only.

${ }^{*} p \leq .05 . * * p \leq .001$.

\section{Triangulation and Summary of Results}

Triangulation of results enabled a further level of analysis among different sources of data. Students in this study who provided the data were from three different cohorts (cases) that each conducted CBR during first-year doctoral coursework in 3 consecutive years, respectively. They responded to one, two, or all three of the different instruments that collectively provided quantitative and qualitative input relevant to addressing the research questions guiding this investigation. All instruments were completed by students during class sessions as part of coursework, which is why we did not conduct interviews. The first year we asked students to reflect on dimensions of effective teamwork, measured by the quantitative items on the CBR Process-Product Questionnaire, a valid and reliable instrument widely used in cooperative decision-making research (see Johnson \& F. Johnson, 2017). The second year we realized that qualitative input would provide nuance on how students experienced CBR, so we developed the CBR Reflection Survey specifically for our program to enable explication; students completed it along with the first instrument. In the third year we asked students to respond to the first two instruments, along with the CBR Self-Assessment Instrument adapted from Jameson, Clayton, Jaeger, and Bringle (2012) to measure how students perceived accomplishment of CBR competencies. Overall patterns across results are consistent, as shown in Table 8.

On the CBR Process-Product Questionnaire, students indicated that they experienced CBR team projects in ways that enhanced mutual listening, understanding, influence, responsibility, satisfaction, and learning (reported in Table 4). This aligns with the self-generated words they used to describe their experiences, which also were overwhelmingly positive (reported in Table 5). A small collection of words across all cohorts, however, also revealed some frustrations, which is consistent with mean scores in the 7- to 8-point range on the 9-point semantic differential scale for each quantitative item on this instrument.

Collectively, CBR Process-Product Questionnaire results (quantitative and qualitative) also align with the thematic findings from responses to the CBR Reflection Survey (reported in Table 6). Specifically, the three major themes that emerged - team skills, technical skills, and management skills - ultimately are broad factors defining effective practice. The descriptive statements classified within each theme elaborate the behaviors/activities that influenced success, or frustrated efforts when missing. Students provided input that illuminated both successful (positive) and lessthan-optimal (negative) aspects. For example, comments that comprised team skills indicated that CBR worked well when clear/ongoing communication, individual strengths, support/trust, and cooperative/collaborative skills were in play-versus not. Comments that comprised technical skills spoke to the importance of knowing and being able to apply various aspects of re- 
search/inquiry - more positive when present, less positive when needed, and more satisfied/successful when students were developing these skills. Finally, comments that comprised management skills indicated an array of logistical aspects of CBR that, when present, made for a smoother experience as opposed to less smooth when not in place - such as mutually developed MOUs defining expectations, scope, boundaries, limits; established timelines, calendars, benchmarks; adequate pacing to keep the project going; and flexibility in making adjustments when warranted.

Table 8. Triangulation of results across cohorts and instruments

\begin{tabular}{|c|c|c|c|}
\hline Instrument & $\begin{array}{c}\text { Cohort 35 } \\
(n=18)\end{array}$ & $\begin{array}{c}\text { Cohort } 36 \\
(n=14)\end{array}$ & $\begin{array}{c}\text { Cohort } 37 \\
(n=15)\end{array}$ \\
\hline \multicolumn{4}{|l|}{ CBR Process-Product } \\
\hline \multicolumn{4}{|l|}{ Questionnaire } \\
\hline $\begin{array}{l}\text { Quantitative range of } \\
\text { means across items } \\
\text { (9-point scale) }\end{array}$ & $7.00-8.00$ & $7.43-8.14$ & $7.47-8.20$ \\
\hline $\begin{array}{l}\text { Qualitative word } \\
\text { analysis }\end{array}$ & $\begin{array}{l}\text { Predominantly } \\
\text { positive } \\
\text { - Some negative, } \\
\text { frustration }\end{array}$ & $\begin{array}{l}\text { Predominantly } \\
\text { positive } \\
\text { - Some negative, } \\
\text { frustration }\end{array}$ & $\begin{array}{l}\text { - Predominantly } \\
\text { positive } \\
\text { - } \begin{array}{l}\text { Some negative, } \\
\text { frustration }\end{array} \\
\end{array}$ \\
\hline $\begin{array}{c}\text { CBR Reflection Survey } \\
\text { Qualitative results }\end{array}$ & $\begin{array}{l}\text { Nonapplicable } \\
\text { (data not collected) }\end{array}$ & \multicolumn{2}{|c|}{$\begin{array}{l}\text { Themes/Factors for Effective Practice } \\
\text { - Team Skills } \\
\text { (collaboration, cooperation, conflict skills) } \\
\text { Technical Skills } \\
\text { (research/inquiry skills) } \\
\text { Management Skills } \\
\text { (expectations/MOUs, } \\
\text { plans/timelines/calendars, } \\
\text { benchmarks/pacing, flexibility/adjustments) }\end{array}$} \\
\hline $\begin{array}{l}\text { CBR Self-Assessment } \\
\text { Instrument } \\
\text { Quantitative } \\
\text { retrospective } \\
\text { pretest-posttest } \\
\text { comparison }\end{array}$ & $\begin{array}{l}\text { Nonapplicable } \\
\text { (data not collected) }\end{array}$ & $\begin{array}{l}\text { Nonapplicable } \\
\text { (data not collected) }\end{array}$ & $\begin{array}{ll}-19 \text { of } 22 \text { items } \\
\text { significantly } \\
\text { different at } \\
p<.001 . \\
1 \text { of } 22 \text { items } \\
\text { significantly } \\
\text { different at } \\
p<.05 . \\
2 \text { of } 22 \text { items not } \\
\text { significantly } \\
\text { different (both } \\
\text { were approaching } \\
\text { significance at } \\
p=.05) .\end{array}$ \\
\hline
\end{tabular}

Finally, results from the CBR Self-Assessment Instrument that compared retrospective pretestposttest mean scores on an array of items (reported in Table 7) aligned with findings from the other two instruments, thereby also supporting the overall effectiveness of CBR as experienced by the doctoral students. For example, statistically significant pre-post comparisons suggest greater perceived ability to (a) collaborate with other students/peers and CBOs (team skills); (b) deal with research, dissertation, and IRB requirements at the doctoral level (technical skills); (c) 
prepare MOUs (management skills); and (d) understand, conduct, and share various aspects of CBR with others - including its history, literature, principles, components - all leveraged for positive social change.

\section{Discussion}

\section{Overall Effectiveness}

The main purpose of this study was to determine the extent to which engaging students in CBR enhances learning and development at the doctoral level. This is particularly important given the current overall lack of studies examining the impact of CBR in graduate education in general, and in doctoral programs specifically. Related purposes were to determine effects of conducting CBR in the education doctorate on students' (a) attitudes toward and competence in CBR, (b) preparation for dissertation research, (c) cooperative/collaborative skills, (d) project management leadership skills and (e) learning how to work with the community to enact broad-based change. The results provide new empirical evidence on the overall effectiveness of integrating CBR into required coursework in doctoral studies by reporting perceived student impact.

We anticipated that all CBR teams would succeed, which they ultimately did. All CBR teams across all cohorts successfully completed their respective projects that culminated in delivering professional-quality written reports and PowerPoint presentations to CBOs, doctoral faculty, and peers/classmates in each respective course in which CBR was conducted. We suspected that accountability for following through would be strong because students were positively interdependent in completing their team goal, which was to conduct a CBR project that provided CBOs with useful information. This goal would have been challenging for any one student to accomplish alone in one year, thus motivating students to work cooperatively to get the job done. The project also was authentic; students knew that $\mathrm{CBOs}$ were counting on them for sound results useful for decision making. However, success was not without some frustration, which some teams experienced more intensely than others. Some of the most common conflicts involved communication (unclear versus clear, irregular versus regular, electronic formats versus in-person conversations - amongst teammates as well as between teams and their CBOs); uncertainty about the nature of the investigation ("fuzzy" goals/targets/questions to investigate as well as "loose" plans that did not provide the type of concrete direction that would have been helpful, especially at the beginning of the project); and juggling full-time jobs, family life, and graduate coursework (in addition to conducting the CBR project while simultaneously taking leadership, research methods, and specialization courses throughout the first year).

Despite such challenges, results overall strongly suggest that integrating CBR into the educational leadership doctorate produces a number of benefits. First, findings indicate that the doctoral students who conducted CBR in this study developed positive attitudes toward CBR because it constituted authentic real-world learning. Although frustrations at certain junctures over time occurred in all CBR teams across all cohorts, this in part may have been because students knew that results mattered to the CBOs. In other words, completing the CBR project went beyond a typical classroom assignment, which may have heightened feelings of conflict amongst students when, periodically, certain teammates did not follow through with their contributions in timely ways (particularly see Table 4, Item 7; and Table 5). Second, participants reported enhanced understanding of and commitment to CBR and how to conduct it. Key areas of growth centered on engaging with community to foster social change, applying the principles of CBR, and being committed to social change (particularly see Table 4, Item 8; Tables 5 and 6; and Table 7, Items 1-8, 13 ). Third, participants reported expanded understanding and application of their technical research skills. These especially included how to frame research questions; construct valid/reliable surveys; deal with challenges of data collection; make choices about how best to analyze, inter- 
pret, display/present data and findings; and submit to the IRB (particularly see Table 6; and Table 7, Items 17-22). Students also came to realize that enacting technical research skills for highquality CBR takes extraordinary time, effort, and persistence. Fourth, participants appreciated more deeply the importance of cooperative/collaborative skills needed to accomplish meaningful tasks larger than oneself. Overall they experienced effective teamwork and cooperative/collaborative decision making, and learned that conflict will occur, so prepare to constructively name, explain, listen, and resolve issues that arise (particularly see Table 4, Items 1-7; Tables 5 and 6; and Table 7, Items 9-12, 14-16, 19). Finally, participants honed project management skills for effective leadership. These included attending to structural considerations such as developing MOUs with CBOs, creating timelines, and pacing progress (particularly see Table 6).

\section{Support for Theoretical Foundations}

The findings also provide additional support for the two theoretical foundations that informed our implementation of CBR - specifically the three principles that underpin CBR and the five basic elements that underpin cooperative teamwork. The CBR literature posits that best practice will evolve from university students and faculty (a) learning and acting on what the CBO believes are important issues/questions to address community needs, (b) seeking multiple forms of data and sharing findings in ways most useful to the community, and (c) applying results for social-justiceoriented change. The cooperative learning literature provides abundant empirical evidence that indicates effective teamwork evolves from (a) positive interdependence-targeting a shared goal that mutually connects all teammates together such that one's success depends on everyone's success, (b) individual accountability — requiring each teammate's unique strengths and contributions for the group to succeed, (c) promotive interaction - teammates facilitating each other's success, (d) social skills - inviting voice, listening, checking for understanding, asking questions, clarifying, summarizing, using appropriate humor to relieve tension, resolving conflict constructively, and implementing other interpersonal skills through which teamwork gets done, and (e) group processing - systematically reflecting on task structures and interpersonal dynamics to determine what is working well and what needs adjusting to improve teamwork. One might call our implementation "cooperative CBR" or "team-based CBR" because it purposefully combined the tenants of both these foundations. The triangulated results previously reported indicate that students embraced the CBR principles and cooperative learning elements to varying degrees, thereby further corroborating their importance for effective practice, as noted in the existing literature.

\section{Strengths and Limitations}

This study has a number of strengths. First, it is one of only a few to examine effects of CBR at the doctoral level, and may be the only one that implemented CBR as a required program component for all students. Second, respected theoretical foundations grounded and guided this study, namely CBR principles and cooperative learning elements. Third, participating doctoral students were diverse in gender, ethnic/cultural background, and professional focus. Fourth, complete data sets were obtained from all three cohorts on the various instruments administered in each of the 3 years. Fifth, two of the instruments (the CBR Process-Product Questionnaire and the CBR SelfAssessment Instrument) had established validity and reliability from their history of repeated use as noted in the literature, although we slightly adapted each by substituting terms for certain words to increase clarity within the Seattle University context and by adding several items to assess perceptions of content/substance learned about the issues investigated and research/inquiry skills. Sixth, independent readers/coders reached agreement on categories and themes for all qualitative data. Seventh, there is evidence that retrospective pretests (the method used in this study) more closely match expert judgment of knowledge and skills than ratings from traditional pretests (see Howard \& Daily, 1979; Klatt \& Taylor-Powell, 2005; Lamb, 2005). Eighth, the retrospective pretest was administered separately from the posttest, which is deemed effective (see Nimon, Zi- 
garmi, \& Allen, 2011). Finally, findings were triangulated, revealing consistent patterns across outcomes throughout.

However, this study also has some limitations. It was conducted at one Jesuit private university in one EdD program situated in the Pacific Northwest of the United States, although data were collected from three different cohorts in 3 separate years. The overall sample was relatively small, although it constituted all students entering the program in each year. All instruments were selfreport; however, three different instruments did enable triangulation of results from quantitative and qualitative data. Although it was not possible to employ control groups, three separate and distinct cohorts did provide input, and results fairly strongly aligned across all. Also, direct measures of achievement were not obtained, such as exams or behavioral observations to assess students' declarative and procedural knowledge of CBR, research/inquiry, cooperative teamwork, or other desired learning. However, as previously noted, all CBR teams - three in Cohort 35, four in Cohort 36, and five in Cohort 37-provided final written reports and PowerPoint presentations to CBOs that met professional standards, thus exhibiting evidence of accomplishment. Finally, written reflective feedback from CBOs was not obtained formally, however interactions and anecdotal comments following the presentations seemed to indicate satisfaction. In fact, three CBOs that Cohort 36 served wanted to (and did) continue pursuing additional CBR projects the following year with Cohort 37, thereby building upon and extending the original investigations. It would be unlikely that CBOs would do so if their experience had not been satisfactory. Also, faculty communicated directly with all CBO partners after the conclusion of the CBR projects conducted by Cohort 37 to discuss partners' satisfaction, what they saw as strengths and limitations of the CBR, and their suggestions for improvement. All partners expressed satisfaction with the final reports and presentations, while also offering ideas to improve communication among all CBR participants, and in one case, suggested that students take on projects with a broader scope.

\section{Implications for Current Practice}

The results of this study demonstrate that team-based CBR can be feasible and effective at the doctoral level, which suggests that faculty should consider integrating CBR into doctoral studies. In doing so, however, faculty also should be prepared to monitor, mentor, facilitate, guide, and intervene appropriately - especially in areas related to assisting students in (a) making sound research decisions (regarding questions, designs, samples, data collection and analysis, interpretation, reporting), (b) establishing structures that keep the process moving forward (developing MOUs, calendars, timelines, benchmarks, and regular reflection for determining useful adjustments), (c) interacting with CBOs in ways that forge partnerships (sometimes aided by faculty who step in as liaison, mediator, or third-party facilitator in more challenging situations), and (d) skillfully managing conflicts likely to arise (amongst teammates and/or between CBR teams and CBOs). This is real work that demands more from both students and faculty than typical class assignments that are given, completed, submitted, graded, then considered done-regardless of quality. In contrast, CBR requires work that maintains a high level of consistent integrity and credibility throughout so as to produce results that CBOs deem useful and from which they can confidently make decisions to advance their initiatives for social change. Ideally, CBR also requires forging partnerships with CBOs, which is challenging given university contexts (quarter/semester intervals; courses and grades that must be completed within those intervals; other rules, regulations, approvals) and $\mathrm{CBO}$ needs and operations (many of which are nonprofits on shoestring budgets with limited staff serving a range of societal needs that demand flexibility). CBR also requires developing sensitivity to cultural differences and the ability to collaborate with individuals and organizations whose backgrounds and values may differ from those of the students. The good news is that, despite these complexities, students in our team-based CBR implementation consistently expressed that they valued the experience and felt an enhanced sense of commitment to working for social justice as leaders in their respective communities. 
We have learned many lessons from continuously implementing CBR across three successive cohorts and systematically gathering input from them across 3 years. One of the major lessons is that the more structure CBR teams build into their work up front and the more attention to structure throughout, along with ongoing communication, the more likely students will be able to deal with unexpected challenges and adjust appropriately when warranted. Structure and regular communication also are useful in dealing with conflicts because preplanned concrete systems for touching base provide foundations for meaningful ongoing reflection, more immediate detection of possible tensions, and the ability to keep disagreements and frustrations small, manageable, and resolvable in mutually beneficial ways.

In fact, we learned a great deal from students' reflections that detailed what they found most challenging as well as helpful (see Table 6, also Stevahn, 2014), and each year made program adjustments accordingly to strengthen best practice developmentally (see Table 1). We learned from Cohort 35 that concrete written expectations, plans, and agreements amongst teammates and with CBOs would be helpful — and that more ongoing, focused, reflection/processing would be useful for taking stock of progress, team dynamics, and interactions with CBOs. Conversations and verbal agreements were a good start, but formalized MOUs, plans, and calendars would provide greater structure, so we built these into the next year. We learned from Cohort 36 that MOUs were indeed useful and that more focused processing (using templates) did engage students in more carefully thinking about what they were learning through CBR that eventually could be applied to dissertation research and their leadership roles in their specialized fields (education, government, health, theology/ministry, nonprofit settings). Finally, we learned from Cohort 37 that more regular meetings amongst teammates and with CBOs further contributed to ongoing communication useful for clarity in shaping direction, formulating plans, staying on track, adjusting when necessary, dealing with issues that arose, and producing high-quality products.

As faculty, we also reflected on lessons learned from mentoring and monitoring students while conducting their CBR studies. First, we learned that it is important to provide one full academic year (three quarters - fall, winter, spring - at a minimum) to plan and conduct a CBR project. High-quality work takes more time than expected, especially when collaborating with other group members and a community partner. Second, we learned that developing long-term, deeper relationships between a community partner and university faculty and students can facilitate higher-quality CBR due to the trust, understanding, and clearer avenues of communication that emerge over time. Third, we learned that it is important to provide students with basic-level understanding of research knowledge and skills they will need to complete their CBR projects prior (yet close) to beginning those projects. Students then can apply and refine their technical research skills during the CBR process.

Ultimately we have come to appreciate that the intensity, rigor, quality, and amount of time students devote to CBR to make it meaningful, useful, and successful provide a doctoral inquiry experience more aligned with the stated outcomes of most EdD programs. We also believe-largely based on results from this 3-year study - that required team-based CBR is a form of social inquiry that may better position doctoral students to practice and internalize a host of skills needed by leaders who effectively facilitate cooperative or collaborative processes, engage in data-based decision making, direct organizational development, and guide organizational learning, We now are in the process of transitioning from the traditional individualistic dissertation model (that we thought CBR in Year 1 would better prepare students for in Year 3) to a team-based CBR dissertation model (conducted in Year 3), through which students working cooperatively will produce a Thematic Dissertation in Leadership Practice (TDiLP) to address a complex social problem in partnership with a $\mathrm{CBO}$ that desires actionable answers. The TDiLP becomes the required social inquiry component of the EdD — providing doctoral rigor, equipping students with the types of 
applied skill sets they need as leaders, and immersing students in the community by connecting them with CBOs advancing social justice initiatives.

\section{Directions for Future Research}

Given the few studies that have been conducted on CBR in graduate programs - particularly at the doctoral level — opportunities are abundant for future research that can continue to provide information toward further discovering what makes effective practice. Possibilities include systematically assessing:

- Student achievement - especially the extent to which students learn what constitutes sound research/inquiry and how to conduct it for social good.

- Impact on CBOs - especially examining the quality of their experiences with CBR by considering their perceived effectiveness of the partnership and usefulness of the process and final product for advancing social change. Future studies that systematically assess CBO satisfaction by determining the degree of fidelity to the Community Standards for Service-Learning developed by Stoecker and Tryon (2009) may enable better understanding of this important aspect of CBR.

- Replication of team-based CBR processes and outcomes - especially across numerous settings (public and private universities) in different geographic locations (across the United States and/or world) with diverse populations (representing different gender, ethnic/cultural, economic/income, social/political characteristics).

- Long-term behavioral impact - especially to determine if participants are more active in and/or devoted to social justice issues and change initiatives in their communities.

- Doctoral program effectiveness - particularly by obtaining data on both immediate and longitudinal effects with respect to program goals, college/school outcomes, and university mission/vision/values, specifically attending to developmental designs that intentionally engage students in experiences to progressively build, expand, and refine their professional competence across a wide array of complex processes and outcomes.

\section{Overall Significance}

This study adds new information to a largely unstudied area of practice in higher education, namely effects of integrating team-based CBR into the education doctorate as a required component of the program. Such information may assist faculty in planning student learning experiences most likely to result in developmentally appropriate professional training at this level - especially EdD programs with a scholar-practitioner, practical-application focus. When the heart of such programs is leadership, our results indicate that team-based CBR can provide a holistic and authentic experience through which numerous complex competencies can be practiced and honedexactly the types of skills and competencies that leaders need to be successful. In fact, many of these are specified in the working principles and design concepts that have emerged from the Carnegie Project on the Education Doctorate (CPED, 2014a, 2014b), based on systematic input from member institutions searching for more effective ways to define, position, deliver, and involve students in the EdD experience - especially distinguishing it from the $\mathrm{PhD}$ that predominantly prepares individuals to become researchers in the traditional sense (primarily faculty in 4year universities), in contrast to highly skilled leaders/practitioners in the community. The CPED working principles and design concepts (shown in Table 9) are similar in many ways to the teambased CBR experience we integrated into Seattle University's EdD program with Cohorts 35, 36, and 37. 
Table 9. Carnegie Project on the Education Doctorate (CPED)

The Professional doctorate in education:

1. Is framed around questions of equity, ethics, and social justice to bring about solutions to complex problems of practice.

2. Prepares leaders who can construct and apply knowledge to make a positive difference in the lives of individuals, families, organizations, and communities.

3. Provides opportunities for candidates to develop and demonstrate collaboration and communication skills to work with diverse communities and to build partnerships.

4. Provides field-based opportunities to analyze problems of practice and use multiple frames to develop meaningful solutions.

5. Is grounded in and develops a professional knowledge base that integrates both practical and research knowledge, that links theory with systemic and systematic inquiry.

6. Emphasizes the generation, transformation, and use of professional knowledge and practice.

\section{Design Concepts}

Scholarly Practitioner... scholarly practitioners blend practical wisdom with professional skills and knowledge to name, frame, and solve problems of practice. They use practical research and applied theories as tools for change because they understand the importance of equity and social justice. They disseminate their work in multiple ways, and they have an obligation to resolve problems of practice by collaborating with key stakeholders, including the university, the educational institution, the community, and individuals.

Signature Pedagogy ... is the pervasive set of practices used to prepare scholarly practitioners for all aspects of their professional work: "to think, to perform, and to act with integrity" (Shulman, 2005, p. 52). Signature pedagogy includes three dimensions, as articulated by Shulman (2005):

1. Teaching is deliberate, pervasive and persistent. It challenges assumptions, engages in action, and requires ongoing assessment and accountability.

2. Teaching and learning are grounded in theory, research, and in problems of practice. It leads to habits of mind, hand, and heart that can and will be applied to authentic professional settings.

3. Teaching helps students develop a critical and professional stance with a moral and ethical imperative for equity and social justice.

Inquiry as Practice ... is the process of posing significant questions that focus on complex problems of practice. By using various research, theories, and professional wisdom, scholarly practitioners design innovative solutions to address the problems of practice. At the center of Inquiry of Practice is the ability to use data to understand the effects of innovation. As such, Inquiry of Practice requires the ability to gather, organize, judge, aggregate, and analyze situations, literature, and data with a critical lens.

Laboratories of Practice... are settings where theory and practice inform and enrich each other. They address complex problems of practice where ideas - formed by the intersection of theory, inquiry, and practice - can be implemented, measured, and analyzed for the impact made. Laboratories of Practice facilitate transformative and generative learning that is measured by the development of scholarly expertise and implementation of practice.

Problem of Practice... is a persistent, contextualized, and specific issue embedded in the work of a professional practitioner, the addressing of which has the potential to result in improved understanding, experience, and outcomes.

Dissertation in Practice ... is a scholarly endeavor that impacts a complex problem of practice.

Note. Copyright 2014 by the Carnegie Project on the Education Doctorate, Inc. (CPED). Reprinted with permission. 
It also is remarkable that the three qualitative themes that emerged in this study that point to effective practice - i.e., the importance of team (social), technical (research), and management (structural) skills for conducting team-based CBR (see Table 6) - are similar to three of five broad evaluator competency domains found in the program evaluation literature (see King \& Stevahn, 2013; Stevahn \& King, 2014), especially since this study was not undertaken to validate such domains, yet provides validity, to a certain extent. Specifically, the three evaluator competency domains that overlap with the three qualitative themes relevant to effective CBR focus on technical (appropriate methodology), management (of projects), and interpersonal (social interaction) aspects of conducting sound evaluation research - the remaining domains focus on evaluator practice that is professional (ethical/principled) and situational (attending to contextual/cultural circumstances in each distinctive evaluation setting). Perhaps the effective practice themes in this study that coincide with the evaluator competency domains emerging from research on essential evaluator knowledge, skills, and dispositions (King, Stevahn, Ghere, \& Minnema, 2001; King \& Stevahn, 2015; Stevahn, King, Ghere, \& Minnema, 2005; Wilcox, 2012; Wilcox \& King, 2014) should be no surprise, as team-based CBR can be considered one of several types of participatory evaluation practice (see King \& Stevahn, 2013, pp. 30-31) aimed at bringing about substantive organizational and/or social change.

Effective leadership often involves initiating, facilitating, and/or involving organizational members in evaluating programs, policies, or practices by gathering data for evidence-based decision making. Educational leadership doctorates that engage students in authentic field-based social inquiry through CBR - either integrated into required coursework or as the culminating dissertation in practice - may be well positioned to equip students with such skills. Furthermore, if the goal of graduate education includes developing leaders who commit to social change, work for the common good, and positively impact social justice - in addition to promoting academic excellence and professional formation - then integrating team-based CBR into the education doctorate holds promise.

\section{References}

Beckman, M., Brandenberger, J. W., \& Smith Shappell, A. (2009). Graduate students and communitybased learning. Academic Exchange Quarterly, 13(3), 45-50.

Bringle, R. G. Clayton, P. H., \& Hatcher, J. A. (2013). Research on service learning. In P. H. Clayton, R. G. Bringle, \& J. A. Hatcher (Eds.), Research on service learning: Conceptual frameworks and assessment. Sterling, VA: Stylus.

Carnegie Project on the Education Doctorate. (2014a). Definition of and working principles for EdD program design. Retrieved from http://cpedinitiative.org/working-principles-professional-practice-doctorateeducation

Carnegie Project on the Education Doctorate. (2014b). Design concept definitions. Retrieved from http://cpedinitiative.org/design-concept-definitions

Case, K. I. (2014). Community-based research in graduate education: Implementing program decisions across the disciplines. Journal of Public Scholarship in Higher Education, 4, 69-92.

Deutsch, M. (1949a). An experimental study of the effects of cooperation and competition upon group processes. Human Relations, 2, 199-231.

Deutsch, M. (1949b). A theory of cooperation and competition. Human Relations, 2, 129-151.

Deutsch, M. (2014). Cooperation, competition, and conflict. In M. Deutsch, P. T. Coleman, \& E. C. Marcus (Eds.), The handbook of conflict resolution: Theory and practice ( $3^{\text {nd }}$ ed.). San Francisco, CA: JosseyBass.

Howard, G. S., \& Dailey, P. R. (1979). Response-shift bias: A source of contamination of self report measures. Journal of Applied Psychology, 64, 144-150. 
Jameson, J. K., Jaeger, A. J., Clayton, P., \& Bringle, R. G. (2012). Investigating faculty learning in the context of community-engaged scholarship. Michigan Journal of Community Service Learning 19(2), 4055 .

Johnson, D. W., \& Johnson, R. T. (1989). Cooperation and competition: Theory and research. Edina, MN: Interaction Book Company.

Johnson, D. W., \& Johnson, R. T. (2005). New developments in social interdependence theory. Genetic, Social, and General Psychology Monographs, 131, 285-358.

Johnson, D. W., \& Johnson, R. T. (2011). Intellectual legacy: Cooperation and competition. In P. T. Coleman (Ed.), Conflict, interdependence, and justice: The intellectual legacy of Morton Deutsch. New York, NY: Springer.

Johnson, D. W., \& Johnson, F. P. (2017). Joining together: Group theory and group skills (12 $2^{\text {th }}$ ed.). New York, NY: Pearson Education.

King, J. A., \& Stevahn, L. (2013). Interactive evaluation practice: Mastering the interpersonal dynamics of program evaluation. Thousand Oaks, CA: Sage.

King, J. A., \& Stevahn, L. (2015). Competencies for program evaluators in light of adaptive action: What? So what? Now what? In J. W. Altschuld \& M. Engle (Eds.), Accreditation, certification, and credentialing: Relevant concerns for U.S. evaluators. New Directions for Evaluation, Number 145 (pp.2137). San Francisco, CA: Jossey-Bass.

King, J. A., Stevahn, L., Ghere, G., \& Minnema, J. (2001). Toward a taxonomy of essential evaluator competencies. American Journal of Evaluation, 22(2), 229-247.

Klatt, J., \& Taylor-Powell, E. (2005). Synthesis of literature relative to the retrospective pretest design. Paper presented at the annual meeting of the American Evaluation Association, Toronto, Canada.

Lamb, T. (2005). The retrospective pretest: An imperfect but useful tool. The Evaluation Exchange. Retrieved from http://www.hfrp.org/evaluation/the-evaluation-exchange/issue-archive/evaluationmethodology/the-retrospective-pretest-an-imperfect-but-useful-tool

Nimon, K., Zigarmi, D., \& Allen, J. (2011). Measures of program effectiveness based on retrospective pretest data: Are all created equal? American Journal of Evaluation 32(1), 8-28.

Porpora. D. (1999). Action research: The highest stage of service-learning? In J. Ostrow, G. Hesser, \& S. Enos (Eds.), Cultivating the sociological imagination: Concepts and models for service-learning (pp.121-133). Washington, DC: American Association for Higher Education.

Puma, J., Bennett, L., Cutforth, N., Tombari, C., \& Stein, P. (2009). A case study of a community-based participatory evaluation research (CBPER) project: Reflections on promising practices and shortcomings. Michigan Journal of Community Service Learning, 16(2), 34-47.

Seattle University. (2016). Mission. Retrieved from http://www.seattleu.edu

Shulman, L. (2005). Signature pedagogies in the professions. Daedalus, 134(3), 52-59.

Stevahn, L. (2014). Integrating co-operative community-based research (CBR) into doctoral leadership studies. Journal of Cooperative Studies, 46(2), 32-45.

Stevahn, L., \& King, J. A. (2014). What does it take to be an effective qualitative evaluator? Essential competencies. In L. Goodyear, E. Barela, J. Jewiss, \& J. Usinger (Eds.), Qualitative inquiry in evaluation: From theory to practice (pp. 141-166). San Francisco, CA: Jossey-Bass.

Stevahn, L., King, J. A., Ghere, G., \& Minnema, J. (2005). Establishing essential competencies for program evaluators. American Journal of Evaluation, 26(1), 43-59.

Stocking, V. B., \& Cutforth, N. (2006). Managing the challenges of teaching community-based research: Insights from two instructors. Michigan Journal of Community Service Learning, 13(1), 56-65.

Stoecker, R. (2003). Community-based research: From practice to theory and back again. Michigan Journal of Community Service Learning, 9(2), 35-46. 
Stoecker, R., \& Tryon, E. A. (Eds.) (2009). The unheard voices: Community organizations and service learning. Philadelphia, PA: Temple University.

Strand, K., Marullo, S., Cutforth, N., Stoecker, R., \& Donahue, P. (2003). Community-based research and higher education: Principles and practices. San Francisco, CA: Jossey-Bass.

Tinkler, B. (2010). Reaching for a radical community-based research model. Journal of Community Engagement and Scholarship,3(2), 5-19.

Wilcox, Y. (2012). An initial study to develop instruments and validate the Essential Competencies for Program Evaluators (ECPE). (Unpublished doctoral dissertation). University of Minnesota, Minneapolis.

Wilcox, Y., \& King, J. A. (2014). A professional grounding and history of the development and formal use of evaluator competencies. Canadian Journal of Program Evaluation, 28(3), 1-28.

\section{Biographies}

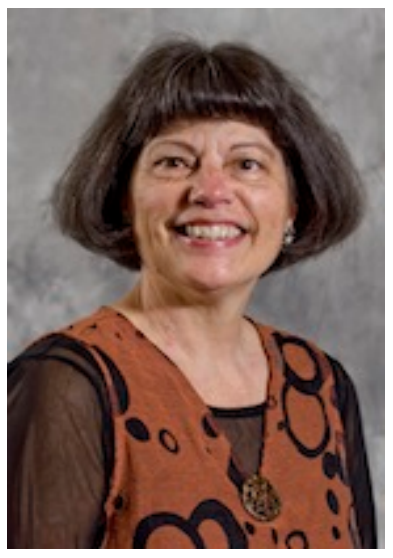

Laurie Stevahn, $\mathrm{PhD}$, is a professor in the Educational Leadership doctoral program in the College of Education at Seattle University where she teaches research/evaluation, leadership, and social justice courses. She specializes in cooperative teamwork, constructive conflict, and participatory forms of inquiry for organizational learning, development, and capacity building. She serves on the board of the International Association for the Study of Cooperation in Education.

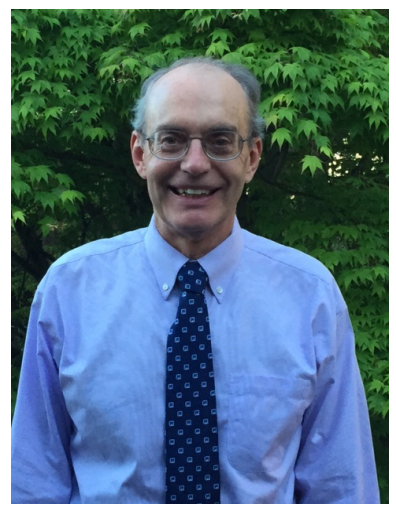

Jeffrey B. Anderson, $\mathrm{PhD}$, is a professor of education at Seattle University where he works in the Master in Teaching (MIT) program. He is a co-editor of the International Journal of Research on ServiceLearning in Teacher Education and a member of the board of the International Center for Service-Learning in Teacher Education.

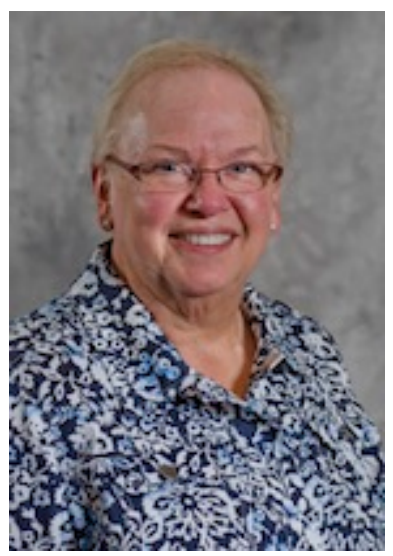

Tana Hasart, EdD, is a visiting professor in the College of Education at Seattle University. She served as president of both Clark College and Pierce College Puyallup, institutions in the Washington Community College system. She is an evaluator and accreditation team lead for the Northwest Commission of Colleges and Universities. While she teaches all aspects of the leadership core studies program, her specialization is organizational development and change. 